NOTES

\title{
ORGAN ALLOCATION AND THE STATES: CAN THE STATES RESTRICT BROADER ORGAN SHARING?
}

\author{
RODERICK T. CHEN*
}

\begin{abstract}
INTRODUCTION
More than twenty thousand patients in the United States received organ transplants in 1997, yet over fifty thousand patients were still waiting for a transplant at the end of that year. ${ }^{1}$ Indeed, over four thousand patients died waiting for a transplant in 1997 . $^{2}$ The scarcity of organs highlights the need for a fair and efficient organ allocation system. Despite this need, not every patient in the United States has the same chance to receive a transplant. For example, in 1995, patients in Iowa had a median wait of twenty-eight days for a liver transplant. Patients in Pennsylvania, however, had to wait a median of 237 days for the same transplant. ${ }^{3}$ State-to-state disparity exists because of policies developed by the United Network of Organ Sharing ("UNOS"), the private organization in charge of the national organ transplantation effort. These policies generally mandate a preference for local transplant recipients in the allocation of human organs. For example, a liver procured in Iowa must first be offered to patients within the area of original procurement, then to patients in the surrounding region, and finally to patients in the rest of the country.
\end{abstract}

* I would like to thank Clark Havighurst for reading earlier drafts, as well as Duncan Douglass and Michael Anstett of the Duke Law Journal for their editorial assistance.

1. See United Network for Organ Sharing, Waiting List (visited October 29, 1999) $<$ http://www.unos.org/newsroom/critdata_wait.htm> (on file with the Duke Law Journal).

2. See id.

3. See Bruce Alpert \& John Pope, Waiting Lists for Livers Debated, NEw ORLEANS TIMES-PICAYUNE, Jan. 26, 1997, at A1. 
On April 2, 1998, the Department of Health and Human Services ("HHS") issued a Final Rule declaring that geographic distinctions are no longer an appropriate basis for allocating organs. ${ }^{4}$ In order to promote broad organ sharing in the United States, the Final Rule directs UNOS to develop an equitable allocation policy using medical urgency as the primary selection criterion. ${ }^{5}$ The Final Rule includes a provision preempting any state law contrary to its directives. $^{6}$

Critical of the motivations underlying the Final Rule, and concerned about its potential impact, ${ }^{7}$ many transplant physicians appealed to Congress to delay or prevent its implementation. ${ }^{8}$ Indeed, their lobbying efforts first succeeded in delaying the implementation of the Final Rule for one year. ${ }^{9}$ In the meantime, HHS issued a clari-

4. See Organ Procurement and Transplantation Network, 63 Fed. Reg. 16,296, 16,297 (1998) (codified at 42 C.F.R. pt. 121 (1998)).

5. See id. (codified at 42 C.F.R. $\S 121.8(a)(3)(i))$.

6. See id. at 16,338 (codified at 42 C.F.R. $\$ 121.12$ ).

7. See, e.g., Putting Patients First: Resolving Allocation of Transplant Organs: Joint Hearing Before the Subcomm. on Health and Env't of the House Comm. on Commerce and Senate Comm. on Labor and Human Resources, 105th Cong. 232, 233 (1998) [hereinafter Hearing on the Final Rule] (statement of Howard M. Nathan, Executive Director of the Delaware Valley Transplant Program) (arguing that the Final Rule would have an "adverse impact on patients and their families"); Caroline Daniel, Transplant System Proposal Stirs Anxiety; Some Fear National Effort to Standardize Wait for Organs Will Hurt Regional Programs, WASH. Post, Aug. 30, 1998, at A6 (noting that the Final Rule could unfairly take organs away from small transplant centers); Dr. Michael DeBakey, Only More Problems With Transplant Policy Change, Hous. CHRON., June 18, 1998, at 39 (arguing that the Final Rule might "reduce the number of people who get transplants and thus cause more patients to die"); Karen Klinka, Transplant Centers Wary of System, DAILY OKLAHOMAN, Mar. 27, 1998, at 1 (noting one transplant physician's view that the government's real motive behind promulgating the Final Rule is to help maintain profits at large transplant centers).

8. See, e.g., Hearing on the Final Rule, supra note 7, at 233 (statement of Howard M. Nathan) (challenging national allocation of organs as inefficient and impractical); Hearing on the Final Rule, supra note 7, at 224 (statement of Dr. William E. Harmon, representing the New England Organ Bank and the American Society of Transplant Physicians) ("[W]e do not believe that national sharing is practical or necessary, except in unusual circumstances. ... Regional sharing is medically sound and reasonable and will go a long way toward equalizing waiting times."); Hearing on the Final Rule, supra note 7, at 212 (statement of Dr. Hector C. Ramos) ("[W]e do not need to redistribute organs at great cost and loss of organ suitability. We need to increase organ donation.").

9. See Omnibus Consolidated and Emergency Supplemental Appropriations Act of 1999, Pub. L. No. 105-277, § 213(a), 112 Stat. 2681, 2681-359 (1998). Additionally, Congress charged the Institute of Medicine, a division of the National Academy of Sciences, to study the possibility of wider organ sharing in the United States. See id. § 213(b), 112 Stat. at 2681-359, 2681-360. On July 20, 1999, the Institute of Medicine released the results of its study, finding that organs could be more widely shared than the current UNOS policy allows. See IOM Panel Recommends Wider Sharing of Organs, Greater Data Access in Final Report, 8 Health L. Rep. (BNA) 
fication of the Final Rule, continuing to insist that organs be allocated based on medical urgency and not geography. ${ }^{10}$ After more delays and much negotiation between HHS and Congress, the Final Rule is now scheduled to take effect by March $2000 .^{11}$

Many states realized that the implementation of the Final Rule could cause some organs procured through state organ donation efforts to be transferred to transplant recipients outside the state. Seven states-Louisiana, South Carolina, Wisconsin, Oklahoma, Texas, Arizona, and Florida-enacted laws placing restrictions on out-of-state organ transfers, thereby attempting to maintain the status quo allocation system. ${ }^{12}$ The majority of these state laws prohibit the transfer of organs recovered within the state to potential out-of-state recipients unless no suitable in-state transplant recipient is found or the states' transplant organizations have a reciprocal organ-sharing agreement. ${ }^{13}$ Because the states had never controlled the allocation of organs before the Final Rule was issued, these laws represent a remarkable development in organ transplant law.

This Note examines the new state laws that restrict the transfer of organs outside the state. Because these laws attempt to recast organ allocation as a states' rights issue, they invite scrutiny on two separate but closely related fronts. First, do the federal statutes and regulations on organ transplantation preempt these state laws? Second, do the state laws place an undue burden on interstate commerce and therefore violate the Commerce Clause of the federal Constitution?

In Part I of this Note, I provide a brief synopsis of the federal and state laws and regulations governing organ transplantation in the United States. I examine in Part II the law of preemption and con-

1192 (July 22, 1999). The report calls for organs to be allocated within regions based on how long the transplant organ can survive outside the body. See id.

10. See Organ Procurement and Transplantation Network, 64 Fed. Reg. 56,650, 56,651-60 (1999) (to be codified at 42 C.F.R. § 121.8) (explaining that the Final Rule does not require a single national list for the allocation of organs).

11. See Laura Meckler, Transplant Rules on Hold, Associated Press, Nov. 19, 1999, available in 1999 WL 28141454.

12. See States Enact Laws to Keep Organs Home as OPO Regions Voluntarily Begin Sharing, 8 Health L. Rep. (BNA) 535 (April 1, 1999).

13. See Ariz. Rev. Stat. AnN. § 36-846 (West 1999); LA. Rev. Stat. Ann. § 17:2353 (West 1999); OKLA. STAT. ANN. tit. 63, § 2204 (West 1999); S.C. CODE ANN. § 44-43-420 (Law. Co-op. 1998); Wis. STAT. ANN. § 157.06(9) (West 1998); Act of June 18, 1999, ch. 615, sec. 4, § $692.0145,1999$ Tex. Sess. Law Serv. (Vernon). Florida's law, in contrast, simply requires that an organ procured in the state be offered to a recipient on a Florida-based organ-sharing list. See FLA. STAT. ANN. § 732.922(6) (West 1999). 
sider whether existing federal organ transplant law preempts the new state laws regulating organ allocation. In particular, I will analyze the Final Rule's preemption statement and demonstrate that it is an invalid exercise of the authority of HHS. I will also show that the state laws are not preempted by any federal statute, including the National Organ Transplant Act of 1984. In Part III, I consider the possibility that the state laws are unconstitutional under the dormant Commerce Clause doctrine. I will argue that these laws are unconstitutional restraints on interstate commerce and should be struck down by the courts. However, applying doctrines like federal preemption and the dormant Commerce Clause may fail to achieve a sound consideration of organ allocation policy. In Part IV, therefore, I raise policy questions not considered by these constitutional doctrines and conclude that Congress should provide clearer instructions for allocating these scarce resources.

\section{The Laws And Policies Governing Organ Allocation}

After HHS issued the Final Rule calling for broader organ sharing in the United States, several states passed laws restricting out-of-state organ transfers. Prior to the passage of these laws, however, the allocation of organs in this country had been governed by a complex array of federal statutes, regulations, and quasi-legal policies.

\section{A. Federal Laws}

In 1984, Congress recognized the need for a national effort to coordinate organ transplantation and passed the National Organ Transplant Act ("NOTA"). ${ }^{14}$ NOTA authorized HHS to make grants for the establishment and operation of organ procurement organizations ("OPOs"). ${ }^{15}$ OPOs are private, nonprofit entities responsible for procuring organs in a defined service area and allocating those organs to suitable recipients. ${ }^{16}$ Each OPO is required to have agreements with hospitals and other health care facilities in its service area to acquire and preserve organs. ${ }^{17}$ In addition, NOTA originally required OPOs to implement "a system to allocate donated organs among

14. National Organ Transplant Act of 1984, Pub. L. No. 98-507, 99 Stat. 2339 (1984) (codified as amended in scattered sections of 42 U.S.C.).

15. See 42 U.S.C. § 273(a) (1994).

16. See id. \$273(b).

17. See id. §273(b)(3). 
transplant centers and patients according to established medical criteria." ${ }^{18}$ Currently, there are sixty-three OPOs operating in the United States. $^{19}$

NOTA also requires HHS to establish a system for overseeing the national exchange of organ transplants, to be called the Organ Procurement and Transplantation Network ("OPTN"). ${ }^{20}$ To that end, HHS must contract with a private nonprofit organization that has expertise in organ transplantation to maintain the OPTN. ${ }^{21}$ The responsibilities of the OPTN include compiling a national list of individuals who need organs and creating a national system to match organs and individuals on the national list based on established medical criteria. ${ }^{22}$ The OPTN must also "assist [OPOs] in the nationwide distribution of organs equitably among transplant patients. ${ }^{, 23}$ Since 1986, UNOS has held the government contract to maintain the OPTN. ${ }^{24}$

While NOTA originally allowed for the allocation of organs on a local basis, Congress has amended the statute twice since its initial passage to reflect its growing concern with the distribution of organs on a nationwide basis. ${ }^{25}$ In 1988, Congress directed the OPOs to allocate donated organs "equitably among transplant patients" rather

18. National Organ Transplant Act, § 201, 99 Stat. at 2048.

19. See Hospitals Told to Report Deaths to Organ Facilities, Wall ST. J., June 18, 1998, at A1; Editorial, New Transplant Rules: Life or Death Choices, S.F. Chron., Apr. 5, 1998, at 6; Richard Saltus, U.S. Seeks a Change in Organ Allocation, Boston Globe, Mar. 27, 1998, at A3.

20. See 42 U.S.C. $§ 274(a)$.

21. See id.

22. See id. $\S 274(\mathrm{~b})(2)$.

23. Id. $\S 274(\mathrm{~b})(2)(\mathrm{D})$.

24. See Fred H. Cate, Human Organ Transplantation: The Role of Law, 20 J. CORP. L. 69, 78 (1995).

25. In addition, Congress strengthened the power of the OPTN by adding section 1138 of the Social Security Act to the Omnibus Budget Reconciliation Act of 1986. Section 1138 required that transplant hospitals and OPOs comply with the rules and regulations of the OPTN as a condition of receiving Medicare and Medicaid reimbursements. See Pub. L. No. 99-509, § 9318(a), 100 Stat. 1874, 2009 (1986) (codified as amended at 42 U.S.C. $\S \S 1320 b-8(a)(1)(B)$, (b)(1)(D) (1994)). Because hospitals and OPOs depend heavily on these reimbursements, section 1138 appeared to make the OPTN's rules binding on these institutions. See James F. Blumstein, Federal Organ Transplantation Policy: A Time for Reassessment?, 22 U.C. DAVIS L. REV. 451, 467-68 (1989); Benjamin Mintz, Analyzing the OPTN Under the State Action DoctrineCan UNOS's Organ Allocation Criteria Survive Strict Scrutiny?, 28 ColuM. J.L. \& Soc. ProbS. 339, 348 (1995). Nevertheless, HHS has subsequently issued a federal regulation declaring that OPTN rules will not bind institutions unless the Secretary formally approves an OPTN recommendation of enforcement. See Organ Procurement and Transplantation Network, 63 Fed. Reg. 16,296, 16,336 (1998) (codified at 42 C.F.R. $§ 121.10(c)$ ). 
than "among transplant centers and patients." ${ }^{26}$ This change reflected Congress's desire to allocate organs based on patient need rather than the needs of transplant centers and hospitals. Congress further amended NOTA in 1990, directing the OPTN to "assist organ procurement organizations in the nationwide distribution of organs equitably among transplant patients." 27

One additional provision of NOTA bears mention. NOTA explicitly prohibits the sale or purchase of human organs for transplantation purposes. ${ }^{28}$ Thus, donors and their families cannot profit from their donations. This, however, does not prevent reasonable payments associated with removal, transplantation, implantation, and storage of a human organ. ${ }^{29}$

\section{B. The Policies of UNOS}

Since 1986, UNOS has held the government contract to manage and create rules of governance for the OPTN. ${ }^{30}$ UNOS is a membership organization comprising every transplant center and organ procurement organization in the United States. ${ }^{31}$ Four goals drive UNOS's organ allocation policy: (1) to enhance the availability of transplantable organs; (2) to allocate organs based on medical criteria, with equal consideration of medical utility and equity; (3) to provide potential transplant recipients with reasonable opportunities for transplants; and (4) to respect the autonomy of persons. ${ }^{32}$ In particular, "medical criteria" includes a consideration of biological compatibility of the donor and the recipient, medical urgency, optimal efficiency in physically moving the organ from the donor to recipient, and medical utility and justice. ${ }^{33}$ Based on these goals, UNOS has de-

26. Health Omnibus Programs Extension of 1988, Pub. L. No. 100-607, § 402(c)(1)(C), 102 Stat. 3048, 3115 (codified as amended at 42 U.S.C. $§ 273($ b)(2)(E)).

27. Transplant Amendments Act of 1990, Pub. L. No. 101-616, § 202(b), 104 Stat. 3279, 3284 (codified as amended at 42 U.S.C $\S 274($ b)(2)(D)).

28. See 42 U.S.C. $\S 274 \mathrm{e}(\mathrm{a})(1994)$.

29. See id. $\$ 274 \mathrm{e}(\mathrm{c})(2)$.

30. See Cate, supra note 24 , at 78 .

31. See Jeffrey Prottas, Human Tissues As Medical Treatment, 65 S. CAL. L. REV. 445, 457 (1991).

32. See United Network for Organ Sharing, UNOS Principles and Objectives of Equitable Organ Allocation (visited Aug. 16, 1999) <http://www.unos.org/about/principles.htm > [hereinafter UNOS Principles and Objectives of Equitable Organ Allocation] (on file with the Duke Law Journal).

33. See id. 
veloped and followed a series of rules governing the allocation of vascular organs, including hearts, livers, and kidneys.

For the allocation of hearts, UNOS provides that such "organs are to be allocated locally first, then within ... [three zones] delineated by concentric circles of five-hundred- and one-thousandnautical-mile radii with the donor hospital at the center." ${ }^{34}$ UNOS defines local allocation as within the service area of the original donor hospital. ${ }^{35}$ Zone A, the first allocation zone, begins outside the donor hospital service area and extends to all transplant centers within 500 miles from the donor hospital. ${ }^{36}$ Zone B extends to all transplant centers at least 500 miles but not more than 1,000 miles from the donor hospital, while Zone $\mathrm{C}$ incorporates all transplant centers beyond 1,000 miles from the donor hospital. ${ }^{37}$ Within these zones, each potential recipient is ranked by a point system that considers the patient's medical urgency, time spent on the waiting list, and blood match. ${ }^{38}$

UNOS's allocation policy for livers has also followed a local preference. Until recently, the policy required that available livers first be offered to local patients, usually within the OPO's service area. ${ }^{39}$ If no suitable local recipient was found, the liver was then made available to recipients within the OPO's surrounding region. ${ }^{40}$

34. United Network for Organ Sharing Policy 3.7.2 (last modified June 25, 1999) $<\mathrm{http}$ //www.unos.org/About/policy_policies.htm> [hereinafter UNOS Policy] (on file with the Duke Law Journal).

35. See id. Policy 3.1.7.

36. See id. Policy 3.7.2.

37. See id.

38. See id. Policies 3.6.2-3.6.4.

39. See id. Policy 3.6.

40. See id. UNOS has defined 11 regions in the United States:

Region 1 - Connecticut, Maine, Massachusetts, New Hampshire, Rhode Island, Vermont

Region 2 - Delaware, District of Columbia, Maryland, New Jersey, Pennsylvania, Northern Virginia, West Virginia

Region 3 - Alabama, Arkansas, Florida, Georgia, Louisiana, Mississippi, Puerto Rico

Region 4 - Oklahoma, Texas

Region 5 - Arizona, California, Hawaii, Nevada, New Mexico, Utah

Region 6 - Alaska, Idaho, Montana, Oregon, Washington

Region 7 - Illinois, Minnesota, North Dakota, South Dakota, Wisconsin

Region 8 - Colorado, Iowa, Kansas, Missouri, Nebraska, Wyoming

Region 9 - New York

Region 10 - Indiana, Michigan, Ohio

Region 11 - Kentucky, North Carolina, South Carolina, Tennessee, Virginia 
If no suitable recipient was found within the region, the liver was then offered to patients nationally. ${ }^{41}$ As with heart transplants, potential liver recipients in each distribution level are ranked according to medical urgency, time spent on the waiting list, and blood match. ${ }^{42}$ Largely in response to criticism of this strict local-preference policy, UNOS revised its liver allocation policy in June 1999 to provide greater consideration of the medical urgency of potential recipients. ${ }^{43}$ However, the new policy continues to provide for liver allocation on a geographic basis.

UNOS's allocation policy for cadaveric kidneys is primarily based on finding the best biological match between the donated organ and a potential recipient, but still gives a preference to local transplant recipients. When a transplantable kidney is harvested, doctors must determine if there are any potential recipients with perfect antigen compatibility. ${ }^{45}$ The more compatible the antigen match, the less likely that the recipient's immune system will reject the donated kidney. ${ }^{46}$ If a perfect match is found, the kidney is first offered to that recipient, no matter where the recipient is located. ${ }^{47}$ If there are multiple potential recipients who match perfectly, however, the kidney usually goes to the potential recipient who is closest geographically to the site of organ procurement. ${ }^{48}$ Absent a perfect match, the kidney is allocated first to local patients within the OPO's service area. ${ }^{49}$ If no suitable recipient is found locally, the kidney usually is offered next

\footnotetext{
Id. Policy 3.5.5.4.

41. See id. Policy 3.6.

42. See id. Policies 3.7.3-3.7.9.

43. United Network for Organ Sharing, News Release (June 25, 1999) $<$ www.unos.org/newsroom/archive_newsrelease_19990625_liver.htm> (on file with the Duke Law Journal); Organ Transplants: UNOS Board of Directors Approves Policy Change Allowing Wider Sharing of Livers, 8 Health L. Rep. (BNA) 1067 (July 1, 1999).

44. See UNOS Policy 3.6, supra note 34.

45. See id. Policy 3.5.2.3. The matching process involves analyzing and comparing six histocompatibility antigens, also called HLA antigens, in the cells of both the donated kidney and the recipient. See Terry Schraeder, New Tack Pays Off on Organ Rejection, Boston Globe, Aug. 17, 1998, at C1.

46. See Schraeder, supra note 45.

47. See UNOS Policy 3.5.2.3, supra note 34

48. See id. Policy 3.5.2.3.1. An exception to this rule is when an OPO is owed a kidney as payback for having sent a kidney to another OPO because of perfect antigen compatibility. See id. Policy 3.5.2.3.1; Prottas, supra note 31, at 460.

49. See UNOS Policy 3.5.5, supra note 34; id. Policy 3.1. In fact, perfect matches rarely occur, making geography the de facto main factor for kidney allocation. See Prottas, supra note
} 31 , at $459-60$. 
to the regional area defined by UNOS ${ }^{50}$ and then nationally. ${ }^{51}$ Within each level of distribution, potential recipients are ranked on a point system that weighs the time spent on the waiting list and the quality of antigen match. ${ }^{52}$ Oddly, the recipient's medical urgency is not a factor in the regional or national allocation of kidneys.

Thus, UNOS allocates vascular organs based on the geographical proximity of potential transplant recipients. Additionally, UNOS allows OPOs to enter into organ-sharing arrangements with other OPOs. ${ }^{54}$ Because these reciprocal arrangements often occur among the OPOs within a state, they usually serve to reinforce the local preference in organ allocation. ${ }^{55}$

Several reasons are given to justify a local preference in organ allocation. First, an organ remains viable for successful transplantation for only a limited time once procured from a human body. ${ }^{56}$ The local preference in allocation minimizes the time an organ spends outside a human body, thereby reducing organ wastage. ${ }^{57}$ Second, transplant professionals contend that the local preference helps keep small community transplant centers open and therefore ensures wider access to organ transplants. ${ }^{58}$ Without the local-preference

50. See UNOS Policy 3.5.5.2, supra note 34. Again, the exception is when an OPO is owed a payback kidney after sharing a kidney with another OPO because of perfect antigen compatibility. See id. Policy 3.5.2.3.1.

51. See id. Policy 3.5.5.3.

52. See id. Policy 3.5.9.

53. See id. Policy 3.5.9.4.

54. See $i d$. Policy 3.7.1.

55. See Erik S. Jaffe et al., Eliminating Artificial Barriers to the Equitable Distribution of Hearts for Transplantation, 20 J. CORP. L. 109, 114-15 (1994) (noting that the primary local distribution unit in a state may actually be multi-OPOs acting within a sharing agreement).

56. Once the heart stops in a human body, the organs begin to deteriorate from the absence of blood circulation and eventually become unsuitable for transplantation. See Marla K. Clark, Solving the Kidney Shortage Crisis Through the Use of Non-Heart-Beating Cadaveric Donors: Legal Endorsement of Perfusion as a Standard Procedure, 70 IND. L.J. 929, 933 (1995).

57. See Hearing on the Final Rule, supra note 7, at 142 (statement of Lawrence G. Hunsicker, President, UNOS) ("The transplant community has found that as the length of time organs go without a blood supply increases, the likelihood of a successful transplant significantly decreases."); Jaffe, supra note 55, at 131 (noting that "UNOS itself has used the issue of ischemic time to discuss without analysis the question of expanding heart distribution").

58. See Putting Patients First: Resolving Allocation of Transplant Organs: Joint Hearing Before the Subcomm. on Health and Env't of the House Comm. on Commerce and Senate Comm. on Labor and Human Resources, 105th Cong. available in 1998 WL 12761471 (statement of the Patient Access to Transplantation Coalition) [hereinafter Patient Access to Transplantation Coalition Statement] ("[The Final Rule would] distribute organs away from small and mid-size transplant centers to a few large centers with a high percentage of hospitalized patients. This may force some of the regional centers, which serve larger numbers of minority 
policy, the argument goes, all transplants would be performed by a few specialized hospitals in the country, such that small transplant centers would fail for lack of business. ${ }^{59}$ If this is indeed the case, the Final Rule would be particularly harmful to minority and poor patients, because these groups tend to utilize local transplant centers. ${ }^{60}$ Some also contend that a local preference in allocation encourages organ donation efforts. ${ }^{61}$ This argument is based on the premise that organ donors are largely motivated by the desire to help patients in their local communities. ${ }^{62}$

\section{The State Anatomical Gift Acts}

Though federal laws and UNOS policies govern the allocation of organs in the United States, the individual states have traditionally regulated the act of organ donation. In 1968, the National Conference of Commissioners on Uniform State Laws adopted the Uniform Anatomical Gift Act ("UAGA"). ${ }^{63}$ The UAGA provides that any individual who is at least eighteen years old may donate his vascular organs. ${ }^{64}$ If a decedent has not indicated a preference for or against organ donation, the decedent's family is authorized to donate the decedent's organs. ${ }^{65}$ Hospitals, procurement organizations, accredited medical schools, and physicians may receive anatomical gifts. ${ }^{66}$ These recipients are required to use the gifts solely for transplantation,

and low-income patients, to close."); Organ Allocation Forum Yields Variety of Opinions, UNOS UPDATE, Mar. 1994, at 3, quoted in Jaffe, supra note 55, at 133 n.97 ("“[A]ny attempt to nationalize the waiting list of recipients would jeopardize the viability of many smaller, yet equally successful programs. These programs are important, keeping recipients close to home, family and the community support system."') (quoting liver-recipient Charles J. Hutson).

59. See supra note 58.

60. See Hearing on the Final Rule, supra note 7, at 142 (statement of Lawrence G. Hunsicker, President, UNOS) (noting that the closure of local transplant programs might adversely affect minority patients more than nonminority patients).

61. See Patient Access to Transplantation Coalition Statement, supra note 58 (arguing that the "nationalization" of organ allocation would "reduce the incentives for vigorous, community-based efforts to increase organ donations"); see also Organ Procurement and Transplantation Network, 63 Fed. Reg. 16,296, 16,304 (1998) (noting the argument that local allocation promotes organ donation and retrieval by local transplant surgeons).

62. See Alpert \& Pope, supra note 3 (quoting Dr. John McDonald as saying that "people who do donate do so knowing that they will go to their friends, colleagues and others in need in their communities"). This premise, however, has been disputed. See infra note 85 and accompanying text.

63. See Uniform Anatomical Gift Act (amended in 1987), 8A U.L.A. 63 (1993).

64. See id. §2(a), 8A U.L.A. at 33.

65. See id. §3(a), 8A U.L.A. at 40.

66. See id. $\S 6(\mathrm{a}), 8$ A U.L.A. at 53. 
therapy, medical education, or research purposes. ${ }^{67}$ Alternatively, an organ donor may designate a specific recipient of the anatomical gift for transplantation purposes. ${ }^{68}$ The UAGA forbids the sale or purchase of human organs for transplantation purposes. ${ }^{69}$ By 1972, every state had adopted an anatomical gift act resembling the UAGA. ${ }^{70}$

\section{The Final Rule}

On April 2, 1998, HHS issued a Final Rule setting three performance goals for UNOS, as the organization that maintains the OPTN. ${ }^{71}$ First, UNOS must define objective medical criteria to be used by all transplant centers in determining whether a patient should be placed on a waiting list for a transplant. ${ }^{72}$ Second, UNOS should develop status categories based on objective medical criteria so that every transplant center would use a common measurement in determining the urgency of a patient's condition. ${ }^{73}$ Finally, UNOS must "develop equitable allocation policies that provide organs to those with the greatest medical urgency, in accordance with sound medical judgment."

The last performance goal essentially calls for UNOS to abandon the local-preference allocation policy. The Final Rule explicitly states: "OPO areas should not be the primary vehicle for organ allocation." 75 Moreover, "[n] either place of residence nor place of listing shall be a major determinant of access to a transplant." ${ }^{, 76}$ In addition, if the Secretary of HHS is dissatisfied with UNOS's allocation poli-

67. See id.

68. See id. §6(b), 8A U.L.A. at 53.

69. See id. § 10, 8A U.L.A. at 58. Oddly enough, UAGA does not prohibit the sale or purchase of organs for purposes other than transplantation, i.e., research or education. See Alexandra Glazier, "The Brain Dead Patient Was Kept Alive" and Other Disturbing Misconceptions; A Call for Amendments to the Anatomical Gift Act 14 (Sept. 21, 1999) (unpublished manuscript, on file with the author).

70. See Cate, supra note 24 , at 71 . Most states have amended their anatomical gift acts to require that hospitals routinely inquire whether each patient is an organ donor and discuss with each patient the option of becoming one. See Uniform Anatomical Gift Act \$5(a), 8A U.L.A. 47 (1993).

71. See Organ Procurement and Transportation Network, 63 Fed. Reg. 16,296, 16,296 (1998) (codified at 42 C.F.R. § 121.8 (1998)); Saltus, supra note 19.

72. See Organ Procurement and Transplantation Network, 63 Fed. Reg. at 16,296 (codified at 42 C.F.R. $\S 121.8(a))$.

73. See id. (codified at 42 C.F.R. $\S 121.8(a)(3)(i)$ ).

74. Id. (codified at 42 C.F.R. $\S 121.4$ ).

75. Id. at 16,312 .

76. Id. at 16,335 . 
cies, she may instruct UNOS to adopt a new policy or develop a policy that UNOS must follow. ${ }^{77}$

HHS justified this increased federal oversight on grounds of equity and fairness. In particular, HHS found that local preference in allocation created vast geographic disparities in waiting times for potential organ transplant recipients. ${ }^{78}$ For example, in 1994-1995, a patient waiting for a kidney transplant at the Oregon Health Sciences University Hospital in Portland, Oregon, had a median waiting time of 147 days, while a patient at the Hospital of the University of Pennsylvania in Philadelphia, Pennsylvania, had a median waiting time of 822 days. ${ }^{79}$ In 1995, the median wait for a liver transplant in Louisiana was sixty-seven days, while the median wait for a liver transplant in Illinois was 349 days. ${ }^{80}$ For heart transplants, the median waiting times in 1992 ranged from fifty-five days in Region 4 (Oklahoma and Texas) to 767 days in Region 11 (Kentucky, North Carolina, South Carolina, Tennessee, and Virginia) ${ }^{8}$

HHS also noted that there are no longer strong reasons for a local preference in allocation. Medical advances now allow many vascular organs to be preserved for much longer periods of time. ${ }^{82}$ Livers, for example, may be kept viable for transplantation for up to eighteen hours without detriment to successful transplantation. ${ }^{83}$ Kidneys can last from twelve to twenty-four hours outside the human body. ${ }^{84}$ Thus, it is possible to have an allocation policy that does not rely on keeping organs within local OPO service areas or regions. Moreover, recent studies demonstrate that organ donors are not motivated to donate simply because it helps the local community, ${ }^{85}$ cast-

77. See id. at 16,300 .

78. See id. at 16,298

79. See id. at 16,311

80. See Alpert \& Pope, supra note 3.

81. See Organ Procurement and Transplantation Network, 59 Fed. Reg. 46,482, 46,486-87 (1994); UNOS Policy 3.5.5.4, supra note 34.

82. The development of the Belzer UW solution in the 1980s was crucial to the dramatic increase in organ survival time outside the human body. See Organ Procurement and Transportation Network, 63 Fed Reg. at 16,298.

83. See id. at 16,304 .

84. See Laurie McGinley, New U.S. Rules on Organ Donors Heighten Debate, Wall ST. J. EUR., Mar. 27, 1998, at UK5A. Hearts and lungs, by contrast, last only from four to six hours outside the human body. See id.

85. See Organ Procurement and Transportation Network, 63 Fed. Reg. at 16,304; OfFICE OF THE INSPECTOR GENERAL, HHS, THE DISTRIBUTION OF ORGANS FOR TRANSPLANTATION: EXPECTATIONS AND PRACTICES 14 (1991). Even UNOS has admitted to the lack of evidence linking donation rates with the degree of localization in organ allocation. See United Network 
ing doubt on the contention that organ donation would decline if local preferences were eliminated. Finally, transplant organs have been characterized as "a national resource to be used for the public good ...."

Anticipating that some states would try to block an organ allocation policy based on wider sharing within the United States, HHS included a preemption clause in the Final Rule:

No State or local governing entity shall establish or continue in effect any law, rule, regulation, or other requirement that would restrict in any way the ability of any transplant hospital, OPO, or other party to comply with organ allocation policies of the OPTN or other policies of the OPTN that have been approved by the Secretary under this part. ${ }^{87}$

If operative, this preemption statement would nullify any inconsistent state or local law that affects organ allocation policy.

\section{E. The New State Organ Allocation Laws}

As HHS anticipated, many states expressed serious concern with the Final Rule's directive for broader organ sharing. Since the promulgation of the Final Rule in April 1997, seven states-Louisiana, South Carolina, Wisconsin, Texas, Oklahoma, Arizona, and Florida-have enacted laws that attempt to block any changes the Final Rule might make in the allocation of organs. ${ }^{88}$ Florida's law mandates that any organ procured in the state must first be offered to potential

for Organ Sharing, The UNOS Statement of Principles and Objectives of Equitable Organ Allocation 24 (1993).

86. Task Force on Organ Transplantation, HhS, Organ Transplantation: IsSUES AND RECOMMENDATIONS 86 (1986); see also AMERICAN MEDICAL AsSOCIATION, Code of Medical Ethics and CuRrent Opinions of the Council on ETHICAL AND JUDICIAL AFFAIRS § 2.16(6) (1994) reprinted in CODES OF PROFESSIONAL RESPONSIBILITY 286

(Rena A. Gorlin ed., 3d ed. 1994) ("Organs should be considered a national, rather than a local or regional, resource.").

87. Organ Procurement and Transportation Network, 63 Fed. Reg. at 16,338 (codified at 42 C.F.R. § 121.12).

88. See Ariz. Rev. Stat. Ann. § 36-846 (West 1999); Fla. Stat. AnN. § 732.922(6) (West 1999); LA. Rev. Stat. AnN. § 17:2353 (West 1999); OKLA. Stat. AnN. tit. 63, § 2204 (West 1999); S.C. CodE ANN. § 44-43-420 (Law. Co-op. 1998); WIS. STAT. ANN. § 157.06(9)(d) (West 1998); Act of June 18, 1999, ch. 615, sec. 4, § 692.0145, 1999 Tex. Sess. Law Serv. (Vernon). Kentucky is considering a similar law. See Organ Transplants: States Enact Laws to Keep Organs Home as OPO Regions Voluntarily Begin Sharing, 8 Health L. Rep. (BNA) 535 (April 1, 1999). 
recipients on a Florida-based organ-sharing list. ${ }^{89}$ The remaining state laws provide that a vascular organ recovered by the state's OPOs shall not be transferred outside the state unless one of the following two conditions exists: (1) no suitable recipient within the state can be found in a reasonable amount of time; or (2) the state's OPOs have a reciprocal agreement with an out-of-state procurement organization. $^{90}$ Such laws, if valid, would inhibit the implementation of a national organ allocation policy based on medical urgency rather than geography. In effect, these laws are intended to maintain the localpreference allocation policy developed by UNOS before the Final Rule.

Yet, the new state laws represent more than just attempts to maintain the status quo. Before the states enacted these laws, the distribution of organs in the United States had been determined by an uneasy relationship between the federal government and transplant professionals. These laws, however, recast organ allocation as a states' rights issue. ${ }^{11}$ In effect, the states argue that they may regulate the distribution of organs pursuant to the police power to protect the health and welfare of their citizens. Thus, these laws not only raise questions about the proper allocation of human organs, but also prompt serious federalism concerns. Specifically, how does the preemption clause of the Final Rule affect the state organ allocation laws? Do the existing federal laws on organ transplantation allow for state involvement in the distribution of organs? Are federal constitutional concerns implicated when states regulate the distribution of organs? Which public- or private-sector body should determine how transplantable organs are distributed? The following parts consider these questions.

89. See Fla. Stat. ANN. § 732.922(6)

90. See Ariz. Rev. Stat. AnN. § 36-846; LA. Rev. Stat. AnN. § 17:2353(6); OKLA. Stat. AnN. tit. 63, § 2204.B.2; S.C. CodE AnN. § 44-43-420; Wis. Stat. AnN. § 157.06(9)(d); Act of June 18, 1999, ch. 615, sec. 4, § 692.0145, 1999 Tex. Sess. Law Serv.

91. Governor Tommy Thompson of Wisconsin has stated, "In this state, we go out and aggressively encourage people to be donors, with me doing public-service announcements. If I'm going to do that, I want those organs to stay in the state and take care of the patients that need it in Wisconsin." Sheryl Gay Stolberg, Fight Over Organs Shifts to States from Washington, N.Y. TIMES, Mar. 11, 1999, at A1. 


\section{Preemption LAW AND the State Organ Allocation Laws}

\section{A. The Law of Preemption}

The apparent conflict between state laws that regulate organ allocation and a federal regulation purporting to preempt these state laws compels an examination of the law of preemption. Preemption is the power of the federal government to supplant state law. ${ }^{92}$ The preemption power is traditionally justified by the Supremacy Clause, which states that "the Laws of the United States ... shall be the supreme Law of the Land; and the Judges in every State shall be bound thereby, any Thing in the Constitution or Laws of any State to the Contrary notwithstanding." $" 93$

In Rice v. Santa Fe Elevator Corp. ${ }^{94}$ the Supreme Court announced that principles of federalism require a presumption against preemption; that is, courts should analyze preemption cases under the assumption "that the historic police powers of the States were not to be superseded by the Federal Act unless that was the clear and manifest purpose of Congress." 95 Therefore, when called upon to consider a preemption case, the Court has focused its analysis on congressional intent to preempt. ${ }^{96}$ Congress's intent is most clear when a federal statute contains explicit language addressing its preemptive effect on state laws. ${ }^{97}$ For example, the Employee Retirement Income Security Act of 1974 ("ERISA") explicitly preempts "any and all State laws insofar as they may now or hereafter relate to any em-

92. See Medtronic, Inc. v. Lohr, 518 U.S. 470, 485 (1996); Fidelity Fed. Sav. \& Loan Ass'n v. de la Cuesta, 458 U.S. 141, 152-54 (1982); Rice v. Santa Fe Elevator Corp., 331 U.S. 218, 22930 (1947). Of course, the federal government may only do so when it acts pursuant to one of its constitutionally delegated powers. See Susan J. Stabile, Preemption of State Law by Federal Law: A Task for Congress or the Courts?, 40 VILL. L. REV. 1, 4 (1995).

93. U.S. CONST. art. VI, cl. 2. However, some scholars have argued that the power of preemption can be derived from the Necessary and Proper Clause. See Harrop A. Freeman, Dynamic Federalism and the Concept of Preemption, 21 DEPAUL L. REv. 630, 638 (1972) (arguing that preemption may be derived from the Necessary and Proper Clause); Stephen A. Gardbaum, The Nature of Preemption, 79 CORNELL L. REV. 767, 781-82 (1994) (arguing that preemption must be derived from the Necessary and Proper Clause).

94. 331 U.S. 218 (1947).

95. Id. at 230 .

96. See Medtronic, 518 U.S. at 485 (stating that state law ought not to be preempted "unless that was the clear and manifest purpose of Congress"') (quoting Rice, 331 U.S. at 230); Cipollone v. Liggett Group, Inc., 505 U.S. 504, 516 (1992) (“"[T] he purpose of Congress is the ultimate touchstone' of preemption analysis.") (quoting Malone v. White Motor Corp., 435 U.S. 497, 504 (1978)).

97. See Jones v. Rath Packing Co., 430 U.S. 519, 525 (1977). 
ployee benefit plan ...." Such a clause leaves little room for judicial discretion in determining whether federal law preempts state law. ${ }^{99}$

However, the Supreme Court has shown tremendous flexibility in finding congressional intent to preempt even in the absence of explicit statutory language. ${ }^{100}$ There are several circumstances where "implied preemption" of state law occurs. Conflict preemption will nullify state law when "compliance with both federal and state regulations is a physical impossibility," obstacle to the accomplishment and execution of the full purposes and objectives of Congress." ${ }^{102}$ State law may also be preempted because a federal law occupies the same field of law. ${ }^{103}$ So-called field preemption occurs when " $[\mathrm{t}]$ he scheme of federal regulation [is] so pervasive as to make reasonable the inference that Congress left no room for the States to supplement it," ${ }^{104}$ or when the federal law "touch[es] a field in which the federal interest is so dominant that the federal system will be assumed to preclude enforcement of state laws on the same subject." ${ }^{105}$

The focus on congressional intent when considering preemption is justified on grounds of judicial restraint, democracy, and federalism. Federal courts should exercise restraint when examining laws passed by Congress, as long as Congress has acted within its constitutional powers. ${ }^{106}$ Because members of Congress are elected and federal judges are not, Congress possesses a stronger mandate to make preemption determinations. Finally, as the only branch of the federal government in which the states have representation (through sena-

98. 29 U.S.C. $§ 1144(a)$ (1994).

99. See Ingersoll-Rand v. McClendon, 498 U.S. 133, 140 (1990) (ruling that ERISA preempted a state common law wrongful-discharge claim because the plaintiff allegedly was discharged in order to prevent the attainment of benefits under an ERISA plan); Corcoran v. United Healthcare, Inc., 965 F.2d 1321, 1331-34 (5th Cir. 1992), cert. denied, 506 U.S. 1033 (1992) (holding that ERISA preempts malpractice claims against utilization review of benefitallocation decisions); see also Stabile, supra note 92, at 19-56 (arguing that Congress should abstain from incorporating express preemption clauses in statutes and instead leave preemption determinations to the courts).

100. See Medtronic, 518 U.S. at 505; Hillsborough County v. Automated Med. Labs., Inc., 471 U.S. 707, 721 (1985).

101. Florida Lime \& Avocado Growers, Inc. v. Paul, 373 U.S. 132, 142-43 (1963).

102. Hines v. Davidowitz, 312 U. S. 52, 67 (1941).

103. See Rice v. Santa Fe Elevator Corp., 331 U.S. 218, 230 (1947).

104. Id.

105. Id.

106. See Ferguson v. Skrupa, 372 U.S. 726, 729 (1963) (noting that "it is up to legislatures, not courts, to decide on the wisdom and utility of legislation"). 
tors and representatives), Congress has the unique ability and responsibility to balance federal and state interests. ${ }^{107}$

Federal regulations issued by administrative agencies can preempt state law to the same extent as federal statutes. ${ }^{108}$ Following the traditional focus on congressional intent, courts should consider "whether Congress intended that federal regulation supersede state law." 109 When Congress has explicitly authorized the agency to preempt, state law can be preempted by federal administrative regulations. ${ }^{110}$

However, the Supreme Court has found administrative preemption even when explicit congressional authorization to preempt does not exist. In United States $v$. Shimer,${ }^{111}$ the Court did not even consider congressional intent when it held that Veterans Administration regulations preempted state law. Instead, the Court applied the following two-pronged test: (1) whether the agency itself intended to preempt state law; and (2) whether the regulations were a proper exercise of the agency's discretionary authority. ${ }^{112}$ The Court's analysis suggested that when Congress grants agencies broad discretionary authority over certain matters, it inherently includes the power to preempt state law.

In Fidelity Federal Savings \& Loan Ass'n v. de la Cuesta, ${ }^{113}$ the Court reaffirmed the two-pronged test used in Shimer. The Court stated: "Where Congress has directed an administrator to exercise his discretion, his judgments are subject to judicial review only to determine whether he has exceeded his statutory authority or acted arbitrarily. When the administrator promulgates regulations intended to preempt state law, the court's inquiry is similarly limited."114 Therefore, an agency may issue regulations that preempt state law where Congress has delegated discretionary authority in the matter to the agency.

107. See Susan Bartlett Foote, Administrative Preemption: An Experiment in Regulatory Federalism, 70 VA. L. REV. 1429, 1432-33 (1984).

108. See Fidelity Fed. Sav. \& Loan Ass'n v. de la Cuesta, 458 U.S. 141, 153 (1982).

109. Louisiana Pub. Serv. Comm'n v. FCC, 476 U.S. 355, 369 (1986).

110. See id.

111. 367 U.S. 374 (1961).

112. See id. at $379-83$

113. 458 U.S. 141 (1982).

114. Id. at 153-54 (citation omitted). 
This standard for administrative preemption strayed from the Supreme Court's traditional focus on congressional intent. ${ }^{115}$ The reason for this deviation may lie in the Court's desire to leave a certain amount of discretion to administrative agencies and even to grant deference to agency interpretations of the law. This deference was formalized in 1984 in Chevron U.S.A. Inc. v. Natural Resources Defense Council. ${ }^{116}$ The Court held in Chevron that the judiciary should defer to reasonable agency interpretations of federal statutes. In particular, "if the statute is silent or ambiguous with respect to the specific issue, the question for the court is whether the agency's answer is based on a permissible construction of the statute." ${ }^{117}$ Yet, this amount of deference to administrative agencies is hard to reconcile with the Court's traditional view of preemption, which involved a presumption against preemption unless congressional intent to preempt was clear. ${ }^{118}$ Though Chevron indicated the Court's willingness to defer to agency interpretations of federal statutes, the Court left unanswered the question of how much deference it would grant agencies that attempt to preempt state law.

In Louisiana Public Service Commission v. FCC, ${ }^{119}$ decided two years after Chevron, the Supreme Court reaffirmed the two-pronged preemption test first used in Shimer. ${ }^{120}$ Rejecting the FCC's claim that its depreciation rules preempted any state rules on the matter, the Court declared:

[A] federal agency may pre-empt state law only when and if it is acting within the scope of its congressionally delegated authority. This is true for at least two reasons. First, an agency literally has no

115. See Howard P. Walthall, Jr., Comment, Chevron v. Federalism: A Reassessment of Deference to Administrative Preemption, 28 CuMB. L. REv. 715, 739-40 (1998) (“[T]he Court has consistently refused to grant deference to an agency's expansive preemption claims, and has conducted an independent analysis into congressional intent.").

116. 467 U.S. 837 (1984)

117. Id. at 843 . The Chevron Court explained that Congress sometimes leaves gaps in statutes, implicitly delegating the power to fill these gaps to administrative agencies. The Court noted other justifications for judicial deference to reasonable agency interpretations. Agency officials, unlike judges, have expertise in the fields they regulate. Moreover, agencies, unlike courts, are accountable to the President and Congress. See id. at 842-44, 865.

118. See Rice v. Santa Fe Elevator Corp., 331 U.S. 218, 230 (1947); see also Paul E. McGreal, Some Rice With Your Chevron?: Presumption and Deference in Regulatory Preemption, 45 CASE W. RES. L. REV. 823, 824 (1995) (discussing the Court's increased accommodation of agency action); Walthall, supra note 115, at 740 (stating that the Court has traditionally not deferred to agency preemption claims but rather has inquired into congressional intent).

119. 476 U.S. 355 (1986)

120. See id. at 374. 
power to act, let alone pre-empt the validly enacted legislation of a sovereign State, unless and until Congress confers power upon it. Second, the best way of determining whether Congress intended the regulations of an administrative agency to displace state law is to examine the nature and scope of the authority granted by Congress to the agency. . . An agency may not confer power upon itself..$^{121}$

The Court applied the Shimer test again in City of New York $v$. $F C C$, ${ }^{122}$ this time holding that FCC regulations preempted state law because the regulations fell within the FCC's discretionary power under the Cable Act. ${ }^{123}$ These two post-Chevron cases confirm that in order for an administrative agency to preempt state law, Congress must have granted broad discretionary rulemaking authority to the agency.

The Supreme Court's reluctance to defer completely to agency determinations involving preemption is understandable. Federal agency administrators are not democratically elected. Though agency administrators are accountable to the President, such accountability may not be a strong-enough check against the potential for overly expansive federal government authority. ${ }^{124}$ Federal agencies, unlike Congress, have no direct ties to the states and are therefore poorly positioned to balance federal and state interests. ${ }^{125}$ Thus, the Supreme Court has consistently held that regulations purporting to preempt state law are valid only if Congress has granted the administrative agency broad discretionary power over the matter.

\section{B. Does the Final Rule Preempt the State Organ Allocation Laws?}

Given the Supreme Court's jurisprudence on administrative preemption, a court considering the Final Rule should find the preemption clause of the Final Rule invalid for several reasons. First, Congress has never explicitly granted HHS the power to preempt state law. The statutory language of NOTA does not include a grant of this

121. Id. (emphasis added)

122. 486 U.S. 57 (1988).

123. See id. at 69-70.

124. See David A. Herrman, To Delegate or Not to Delegate—That is Preemption: The Lack of Political Accountability in Administrative Preemption Defies Federalism Constraints on Government Power, 28 PAC. L.J. 1157, 1169-70 (1997) (discussing the importance of accountability and elected decisionmakers in the federal system).

125. See Walthall, supra note 115 , at 756 . 
power to HHS. ${ }^{126}$ Moreover, the legislative history of the Act makes no reference to preemption. ${ }^{127}$

Furthermore, the Final Rule's preemption clause does not meet the two-pronged test for administrative preemption developed in Shimer. Under the Shimer test, judicial review of the Final Rule's preemption clause would focus both on whether HHS intended to preempt state law and on whether the Final Rule fell within the scope of discretionary authority conferred upon HHS. Because HHS explicitly inserted a preemption statement in the Final Rule, the first prong of the Shimer test would easily be satisfied.

However, neither the statutory language nor the legislative history of NOTA indicates that Congress granted HHS broad discretionary authority over organ allocation policy. When Congress passed NOTA in 1984, it wanted to develop a "national policy regarding the appropriate federal and private sector roles in organ transplantation." ${ }^{128}$ To that end, NOTA authorized HHS to give grants to OPOs and to establish, by contract, the OPTN. ${ }^{129}$ Yet, a Senate Report from the Committee on Labor and Human Resources made clear that "the national coordinating effort, while stimulated by the federal government and [NOTA], should nonetheless be located in the private sector, rather than in government." ${ }^{130}$ This statement reflects Congress's desire to limit the role of government bureaucracy in organ transplantation.

Though subsequent amendments to NOTA indicate Congress's preference for a nationwide equitable distribution of organs, ${ }^{131} \mathrm{Con}$ gress placed the power to create such policies with the OPOs and the OPTN (managed by UNOS), not with HHS. In the 1988 Amendments to NOTA, Congress stated that "the OPO is responsible for allocating organs equitably among the patients who are in need of a transplant," 132 and that the OPTN should "facilitate an equitable allocation of organs among patients.... [and] resolve any issues regarding the fair and effective distribution of organs." ${ }^{133}$ Congress declared that it did not wish "the statute to be read as establishing a prefer-

\footnotetext{
126. See 42 U.S.C. $\$ \S 273-74$ (1994).

127. See S. REP. No. 98-382, at 13-17 (1984), reprinted in 1984 U.S.C.C.A.N. 3975, 3979.

128. Id. at 13 .

129. See supra notes 20-23 and accompanying text.

130. S. REP. No. 98-382, at 15 (emphasis added).

131. See supra notes 25-27 and accompanying text.

132. S. REP. No. 100-310, at 12 (1988), reprinted in 1988 U.S.C.C.A.N. 4236, 4240.

133. Id. at $13-14$.
} 
ence for, or against, distribution [of organs] within the service area of the OPO." ${ }^{134}$ In addition, because the OPTN was charged with making quasi-legal policy decisions, the OPTN must to follow appropriate rulemaking procedures such as holding public hearings. ${ }^{135}$ Congress intended HHS to serve the relatively limited role of publishing notices of public hearings and receiving public comment. ${ }^{136}$

The 1990 amendments to NOTA confirmed that Congress did not grant broad discretionary authority to HHS to make organ allocation policy. Congress noted that "[t]he OPTN, in addition to maintaining the single national list of all patients waiting for an organ transplant, is also charged with setting much of national transplant policy." 137 To this end, the OPTN may make "policy decisions on such matters as assuring the organ sharing system is fair and equitable to patients. ${ }^{138}$ HHS, on the other hand, should promulgate performance standards on OPO service areas to ensure maximum efficiency and effectiveness in organ distribution. ${ }^{139}$ Indeed, the legislative history of NOTA and its amendments indicates that HHS's authority is rather limited. Because HHS does not have broad discretionary authority over organ allocation, it may not promulgate regulations that preempt state law. Thus, a court considering this issue should invalidate the Final Rule's preemption clause and hold that the state organ allocation laws are not affected by the Final Rule.

\section{Does NOTA Preempt the State Organ Allocation Laws?}

Despite the fact that the Final Rule's preemption clause is probably invalid, the state organ allocation laws might still be preempted by NOTA itself. While NOTA does not explicitly preempt state law, a court could find that NOTA implies preemption under either conflict preemption or field preemption analysis.

At present, the case for conflict preemption is weak. Federal and state laws do not appear to be in true conflict, since the state laws and NOTA could coexist under the local preference in allocation policy followed by UNOS. However, if UNOS changes its allocation policy

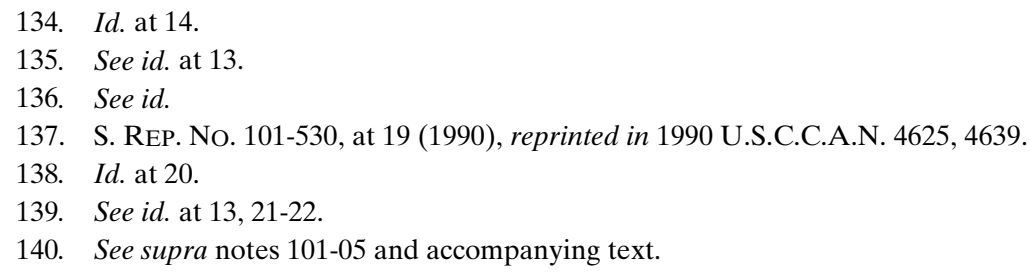

140. See supra notes 101-05 and accompanying text. 
to provide for broader organ sharing among states, the quasi-legal UNOS policies might conflict with the new state laws, necessitating conflict preemption analysis. Although the courts have yet to consider this scenario, it would seem highly irregular for a court to rule that a private organization's policies preempt state legislative determinations. ${ }^{141}$

A better case can be made that NOTA preempts the entire field of organ allocation. As stated earlier, field preemption may occur either when a federal regulatory scheme is pervasive enough to allow the conclusion that Congress left no room for the states to supplement federal control, or when a federal law governs a field in which there is a dominant federal interest. ${ }^{142}$ To be sure, Congress acknowledged the existence of the state anatomical gift acts and allowed them to stand when it enacted NOTA in $1984 .{ }^{143}$ One may therefore argue that Congress never intended NOTA to create a pervasive federal regulatory scheme that preempts the entire field of organ transplantation. ${ }^{144}$ Yet, an equally plausible interpretation would be that Congress regarded the state laws as dealing exclusively with organ donation and not the field of organ allocation. If transplant organs are indeed "a national resource,", 145 a court conceivably could find that the federal interest is sufficiently dominant in the field of organ allocation to preempt any state law that touched this field.

Such a field preemption argument is nevertheless a tenuous one. The Supreme Court has generally been reluctant to find a dominant federal interest that preempts an entire field of law. ${ }^{146}$ Certainly, the

141. A related question is one that has been considered by Benjamin Mintz: can UNOS policy be considered state action? Mintz notes that state action might exist if the government compels or encourages UNOS decisions. See Mintz, supra note 25, at 374. It would seem that the Final Rule would fulfill this requirement.

142. See supra notes $103-05$ and accompanying text.

143. See S. REP. No. 98-382, at 3 (1984), reprinted in 1984 U.S.C.C.A.N. 3975, 3977. The Senate Report acknowledged that the "present system is a mixture of private sector initiatives and governmental involvement on both the State and Federal levels." Id.

144. In any case, the pervasiveness of federal regulation constitutes weak evidence of congressional intent to preempt, since modern regulation often requires comprehensive rules. See New York Dep't of Soc. Servs. v. Dublino, 413 U.S. 405, 414-15 (1973) (rejecting the argument that the comprehensive nature of the Work Incentive Program preempted a New York state work program); McGreal, supra note 118, at 837 (discussing the weakness of comprehensiveness as an indicator of congressional intent to preempt an entire field).

145. See supra note 86 .

146. See, e.g., Hillsborough County v. Automated Med. Lab. Inc., 471 U.S. 707, 719 (1985) (finding insufficient support for the claim that federal regulations establishing minimum standards for the collection of blood plasma preempt county ordinances governing blood plasma centers); McGreal, supra note 118, at 835-37 (stating that the Court has been hesitant to find 
Court has had little problem finding state law preemption when foreign affairs or national security interests are involved. ${ }^{147}$ Yet, the Court remains committed to the notion that the states are endowed with the power to regulate the health and welfare of their citizens and that this power should not be preempted absent clear congressional purpose to do so. ${ }^{148}$ The courts are thus likely to find that NOTA does not provide a sufficiently strong indication of a dominant federal interest in organ allocation to preempt the state laws.

\section{The Dormant Commerce Clause and the State Organ ALLOCATION LAWS}

\section{A. Dormant Commerce Clause Doctrine}

Even if existing federal law does not preempt the state organ allocation laws, courts may still find them invalid under the dormant Commerce Clause. The dormant Commerce Clause allows courts to strike down state and local laws that are unduly burdensome on interstate commerce. ${ }^{149}$ This judicially inferred doctrine is derived from Article I, section 8 of the U.S. Constitution, which grants Congress the power to regulate commerce among the states. In Gibbons $v$. Ogden, ${ }^{150}$ one of the first cases to consider the extent of the commerce power, Chief Justice John Marshall recognized that granting Congress the power to regulate interstate commerce necessarily precluded the states from regulating interstate commerce. ${ }^{151}$ Since Gibbons, federal courts have invoked this dormant Commerce Clause power to invalidate state and local laws. ${ }^{152}$

One of the fundamental rationales underlying the dormant Commerce Clause is that states should not be allowed to enact legis-

\footnotetext{
field preemption solely on the basis of the comprehensiveness of a particular federal program).

147. See, e.g., Hines v. Davidowitz, 312 U.S. 52, $62-69$ (1941) (striking down a state law that required aliens to register with the state Attorney General).

148. See supra note 95 and accompanying text.

149. See Southern Pac. Co. v. Arizona, 325 U.S. 761, 767-69 (1945); South Carolina State Highway Dep't v. Barnwell Bros., Inc., 303 U.S. 177, 184-86 (1938); Cooley v. Board of Wardens, 53 U.S. (12 How.) 299, 317-21 (1851).

150. 22 U.S. (9 Wheat.) 1 (1824).

151. See id. at 196-222.

152. See, e.g., Chemical Waste Management, Inc. v. Hunt, 504 U.S. 334, 344-48 (1992) (declaring unconstitutional a state law that required out-of-state companies, but not in-state companies, to pay hazardous waste-disposal fees); Southern Pac. Co., 325 U.S. at 779-84 (striking down a state law that limited the length of railroad trains operating in the state).
} 
lation that discriminates against residents of other states. ${ }^{153}$ Such protectionist legislation creates inefficiencies and harms the nation's economy. ${ }^{154}$ Indeed, the Framers created a federal commerce power in part because of their concern over the proliferation of state laws that taxed other states for the use of in-state ports. ${ }^{155}$ It would be unfair for a state to enact laws that harm nonresidents because nonresidents lack the political representation that would allow them to change discriminatory laws. ${ }^{15}$

Though numerous tests have been used to determine when states unconstitutionally regulate interstate commerce, ${ }^{157}$ the modern ap-

153. See Donald H. Regan, The Supreme Court and State Protectionism: Making Sense of the Dormant Commerce Clause, 84 MICH. L. REV. 1091 (1986). In fact, Professor Regan argues that the dormant Commerce Clause should only be used to strike down purposeful state protectionism, no more and no less. See id. at 1098.

154. See id. at 1118 ("[P]rotectionism is inefficient because it diverts business away from presumptively low-cost producers without any colorable justification in terms of a benefit that deserves approval from the point of view of the nation as a whole.").

155. See ERwin Chemerinsky, Constitutional Law: Principles \& POlicies 309 (1997). James Madison envisioned the commerce power "as a negative and preventive provision against injustice among the States themselves, rather than as a power to be used for the positive purposes of the General Government ...." Letter from James Madison to J.C. Cabell (Feb. 13, 1829), in 3 The Records of the Federal Convention of 1787, at 478 (Max Farrand ed., 1937).

156. See South Carolina State Highway Dep't v. Barnwell Bros., Inc., 303 U.S. 177, 185 n.2 (1938) ("WW]hen the regulation is of such a character that its burden falls principally upon those without the state, legislative action is not likely to be subjected to those political restraints which are normally exerted on legislation where it affects adversely some interests within the state.”). Numerous legal scholars have criticized the dormant Commerce Clause doctrine. Some note that the Constitution does not expressly prohibit states from enacting protectionist legislation. See Julian N. Eule, Laying the Dormant Commerce Clause to Rest, 91 YALE L.J. 425, 435-37 (1982) (arguing that while the dormant Commerce Clause may have served a purpose in the country's infancy, the doctrine is no longer needed today); Martin H. Redish \& Shane V. Nugent, The Dormant Clause and the Constitutional Balance of Federalism, 1987 DUKE L.J. 569, 571 (commenting that the Constitution does not authorize the courts to invalidate state commerce legislation). Others argue that Congress, and not unelected federal judges, should decide whether state law unduly burdens interstate commerce. See Patrick C. McGinley, Trashing the Constitution: Judicial Activism, the Dormant Commerce Clause, and the Federalism Mantra, 71 OR. L. REV. 409, 453-56 (1992); Mark Tushnet, Rethinking the Dormant Commerce Clause, 1979 WIS. L. REV. 125, 150. These arguments, while meritorious, are beyond the scope of this Note. It is sufficient to say that the courts have continued to use the dormant Commerce Clause in the face of these arguments.

157. See DiSanto v. Pennsylvania, 273 U.S. 34, 41-42 (1927) (analyzing whether a state law that required persons selling steamship tickets for foreign travel to obtain a license and bond from the state directly interfered with interstate commerce or only had an indirect effect); Cooley v. Board of Wardens, 53 U.S. (12 How.) 299, 314 (1851) (illustrating the tension between national subject matters and local matters); Gibbons v. Ogden, 22 U.S. (9 Wheat.) 1, 203-12 (1824) (making the distinction between the improper regulation of commerce and the proper exercise of the state's police power). 
proach has been to employ a two-step review. ${ }^{158}$ A court must first inquire whether the state law is a measure that facially discriminates against out-of-state economic interests. ${ }^{159}$ An example of such discrimination is when a state law overtly blocks the flow of goods at its borders in order to boost the local economy. ${ }^{160}$ A court considering such a blatant form of economic discrimination will presume the state law to be unconstitutional and will invalidate it. ${ }^{161}$ On the other hand, if the state law seeks to advance a "legitimate local public interest" and does not discriminate against interstate commerce on its face, the law will be upheld unless the burden it places on interstate commerce is "clearly excessive" compared to its local benefits. ${ }^{162}$ In employing this balancing test, a court will consider the "nature of the local interest involved," and "whether it could be promoted as well with a lesser impact on interstate activities." 163

A state or local law can facially discriminate against interstate commerce in a number of ways. For example, a state could impose requirements on out-of-state articles of commerce that do not apply to in-state articles. ${ }^{164}$ Often, states attempt to prevent the export of resources, thereby preventing out-of-state residents from using these resources. Such laws frequently have been invalidated by the Supreme Court. In Hughes v. Oklahoma, ${ }^{165}$ the Court struck down an Oklahoma law that forbade the transport of minnows outside Oklahoma if the minnows were procured from in-state waters. ${ }^{166}$ The Court found that "such facial discrimination invokes the strictest scrutiny of any purported legitimate local purpose," and it struck down the law because no such purpose was found. ${ }^{167}$ New England

\footnotetext{
158. See Philadelphia v. New Jersey, 437 U.S. 617, 624 (1978); Pike v. Bruce Church, Inc., 397 U.S. 137, 142 (1970); Southern Pac. Co. v. Arizona, 325 U.S. 761, 767 (1945).

159. See Philadelphia, 437 U.S. at 624.

160. See id. at 623-29; see also Welton v. Missouri, 91 U.S. 275, $276-77$ (1875) (declaring invalid a law that required sellers of out-of-state goods to obtain a license to sell in Missouri).

161. See Philadelphia, 437 U.S. at 624.

162. Pike, 397 U.S. at 142 .

163. Id.

164. See, e.g., Lewis v. BT Inv. Managers, Inc., 447 U.S. 27, $42-44$ (1980) (invalidating a Florida law that explicitly discriminated against bank holding companies whose principal operations were outside of Florida); Baldwin v. G.A.F. Seelig, Inc., 294 U.S. 511, 524-26 (1935) (striking down a New York law restricting the prices of milk products from out-of-state producers and preventing such products from being sold at a price lower than in-state milk).

165. 441 U.S. 322 (1979).

166. See id. at 338 .

167. Id. at 337.
} 
Power Co. v. New Hampshire ${ }^{168}$ presented a similar situation. There, a New Hampshire law prohibited a utility company from conveying electricity out of the state except with the permission of New Hampshire's public utility commission. ${ }^{169}$ The Court struck down the law as an unlawful facial restriction on interstate commerce. ${ }^{170}$ Finally, in Philadelphia $v$. New Jersey, ${ }^{171}$ the Court invalidated a New Jersey law that prevented the city of Philadelphia from sending its wastes to New Jersey landfills. ${ }^{172}$ The Court ruled that this law violated the dormant Commerce Clause because it "erect[ed] a barrier against the movement of interstate trade."

Significantly, states have often enacted laws that have reciprocity requirements, which allow a nonresident to access the state's resources only if the nonresident's state grants similar benefits to the state's citizens. The Supreme Court, however, has consistently ruled that such requirements are facially discriminatory and thus presumptively unconstitutional. For example, in Great Atlantic \& Pacific Tea Co. v. Cottrell, ${ }^{174}$ the Court invalidated a Mississippi law that allowed milk to be shipped into Mississippi from another state only if the other state would accept milk from Mississippi on a reciprocal basis. ${ }^{175}$ In doing so, the Court patently rejected Mississippi's contention that the reciprocity clause served vital interests in maintaining the health and welfare of its citizens. ${ }^{176}$ Similarly, in Sporhase v. Nebraska, ${ }^{177}$ the Court rejected Nebraska's reciprocity requirement for the interstate transfer of groundwater. ${ }^{178}$ The Court found that a reciprocity requirement acted as "an explicit barrier to commerce" between states. $^{179}$

\footnotetext{
168. 455 U.S. 331 (1982).

169. See id. at 335.

170. See id. at 331.

171. 437 U.S. 617 (1978).

172. See id. at 629.

173. Id. at 628 .

174. 424 U.S. 366 (1976).

175. See id. at 381 .

176. See id. at 375.

177. 458 U.S. 941 (1982).

178. See id. at $957-58$.

179. Id. at 957.
} 


\section{B. Are the State Organ Allocation Laws Unconstitutional Under the Dormant Commerce Clause?}

Courts considering the new state laws restricting out-of-state organ transfers should strike them down as violations of the dormant Commerce Clause. Crucial to this argument is a determination that the distribution of organs constitutes interstate commerce. The limited case law on this issue supports this conclusion. In 1988, the U.S. District Court of New Jersey decided Delaware Valley Transplant Program v. Coye, ${ }^{180}$ a case involving a New Jersey regulation that designated a New Jersey organ bank as "the sole organ procurement agency for New Jersey." ${ }^{181}$ The district court could find no other purpose for the designation except to "preclude other organizations from procuring organs within the State." ${ }^{182}$ Accordingly, the court invalidated the regulation under the dormant Commerce Clause, calling it a "highly protectionist effort to keep organs retrieved in New Jersey from being used in out-of-state transplant operations." thus recognized that organ distribution affects and involves interstate commerce.

To counter a dormant Commerce Clause challenge, the states might argue that organ procurement and distribution do not involve interstate commerce. After all, NOTA and the UAGA both expressly prohibit the purchase and sale of human organs for transplantation purposes. ${ }^{184}$ This argument, however, employs circular reasoning. Congress acted pursuant to its power to regulate interstate commerce when it prohibited the purchase and sale of human organs. Indeed, organ procurement and distribution must involve interstate commerce if NOTA is valid at all. ${ }^{185}$ United States $v$. Wang ${ }^{186}$ supports this conclusion. There, the district court found that the "'transfer [of] human organs ... for valuable consideration for use in human transplantation ... [could] affect interstate commerce." ${ }^{187}$ Ultimately, it

\footnotetext{
180. 678 F. Supp. 479 (D.N.J. 1988).

181. Id. at 481 .

182. Id. at 482 .

183. Id. at 481 .

184. See supra notes $28-29,69$ and accompanying text.

185. The Supreme Court used a similar rationale in Sporhase v. Nebraska, 458 U.S. 941 (1982). The Court noted that if groundwater is not an article of commerce, it not only exempts the state law from dormant Commerce Clause analysis, but also curtails Congress's affirmative power to implement its own regulations on the matter. See id. at 953.

186. No. 98 Cr. 199(DAB), 1998 WL 556160 (S.D.N.Y. Aug. 31, 1998).

187. $I d$. at $* 2$ (quoting the indictment).
} 
would be impossible to characterize organ transplantation as having no relation to interstate commerce. Many OPOs arrange the procurement and allocation of organs for several states and therefore necessarily engage in interstate activities. ${ }^{188}$ The fact that OPOs share some organs with out-of-state OPOs, either through reciprocal agreements or UNOS policies, indicates that organ procurement and distribution involves interstate commerce.

Accepting that organ distribution involves interstate commerce, a court must then consider whether the state organ allocation laws discriminate against interstate commerce. The state laws provide that all organs harvested within the state should not leave the state unless there is no suitable recipient found within the state or there is a reciprocal agreement with an out-of-state procurement organization. ${ }^{189}$ It would appear that interstate commerce is clearly burdened since the states have curtailed the transfer of organs across state lines. Indeed, similar state laws that burdened the flow of interstate commerce were struck down in Philadelphia v. New Jersey and Hughes v. Oklahoma. ${ }^{190}$ Additionally, the reciprocity clauses in many of the state organ allocation laws are similar to the reciprocity clause that the Supreme Court deemed facially discriminatory to interstate commerce in Great Atlantic \& Pacific Tea Co. ${ }^{191}$

The states might contend that their laws promote a legitimate local purpose, namely, the preservation of a scarce resource. In Sporhase v. Nebraska, ${ }^{192}$ the Supreme Court acknowledged that a state may act within its police power "to conserve and preserve for its own citizens [a] vital resource in times of severe shortage." Court reasoned that a "demonstrably arid State conceivably might be able to marshal evidence to establish a close means-end relationship between even a total ban on the exportation of water and a purpose to conserve and preserve water." ${ }^{, 194}$ Similarly, the states might be able

188. The New England Organ Bank, for example, serves Maine, New Hampshire, Vermont, Massachusetts, Connecticut, and Rhode Island. See The New England Organ Bank (visited Aug. 17, 1999) <http://www.neob.org> (on file with the Duke Law Journal). Similarly, LifeCenter Northwest serves Alaska, Washington, Montana, and Northern Idaho. See LifeCenter Northwest (visited Aug. 17, 1999) <http://www.lcnw.org/about_fs.html> (on file with the Duke Law Journal).

189. See supra notes $88-90$ and accompanying text.

190. See supra notes $165-73$ and accompanying text.

191. 424 U.S. 366, 372-73 (1976).

192. 458 U.S. 941 (1982).

193. Id. at 956.

194. Id. at 958 . 
to classify human organs as a scarce resource ${ }^{195}$ and demonstrate that the restriction on interstate commerce is crucial to maintaining the supply of human organs within the state. Yet, the Sporhase Court eventually struck down the state law that purported to conserve groundwater, noting that the state's interest in conserving groundwater had an interstate dimension: "[T]here is a significant federal interest in conservation as well as in fair allocation of this diminishing resource." ${ }^{196}$ Human organs can easily be characterized in a similar fashion. Human organs have never been considered a state resource; to the contrary, both the Task Force on Organ Transplantation and the American Medical Association have said that organs are national resources. ${ }^{197}$ Thus, courts considering the new state laws should find these laws unconstitutional under the Sporhase rationale.

\section{CONSIDERING Organ Allocation Policy}

\section{A. How Should Organs Be Allocated?}

Underlying these deliberations on preemption law and the dormant Commerce Clause are issues of health care law and policy beyond a court's jurisdiction. How should transplantable organs be distributed? Who ought to decide how they are distributed? Should organ allocation policy be left to health care providers, or should the distribution of organs be based on a consumer-driven market? What is the proper role of the federal government in organ allocation? While it is clearly appropriate for the courts to settle controversies involving the constitutionality of certain laws, courts should be wary of making these broader policy determinations.

Many factors can and should be considered in allocating scarce resources like transplant organs. HHS implicitly argues that justice and fairness should be the primary consideration by calling for organ allocation based on the medical urgency of the patients. ${ }^{198}$ Yet, justice and fairness would also seem to demand that the patient who has

195. Although about 20,000 transplants were performed in 1996, about 4,000 people died in the same year while waiting for a transplant. See Organ Procurement and Transplantation Network, 63 Fed. Reg. 16,296, 16,296 (1998).

196. See Sporhase, 458 U.S. at 953; see also Arizona v. California, 373 U.S. 546, 564-65 (1963) (affirming the Boulder Canyon Project Act as a comprehensive scheme for the apportionment of mainstream waters of the Colorado River among several states).

197. See supra note 86 .

198. See supra Part I.D. 
spent the longest time on a waiting list be given first priority. ${ }^{199}$ How does one reconcile these competing issues of fairness? Perhaps the "fairest" option would be to hold a random selection lottery to determine who will receive an organ transplant. ${ }^{200}$

Still, many others argue that medical utility should be the primary factor in organ allocation. ${ }^{201}$ This principle seems to be the guiding force behind the local-preference allocation policy followed by UNOS. Fewer organs would be wasted if the organ spent as little time as possible outside a human body and without a blood supply. ${ }^{202}$ But other valid allocation methods based on medical utility also exist. Why not give the organ to the recipient with the best biological match? Indeed, cadaveric kidneys are allocated this way. Alternatively, organs could go to the healthiest patients first, rather than to the sickest, which could mean higher overall survival rates and less need for retransplantation later. Lastly, it has been argued that the recipient's willingness to comply with a prescribed treatment regimen after organ transplantation should also figure into the allocation decision. ${ }^{203}$

Even more controversial are the subjective factors that could be used to select transplant recipients. Should the patient's social worth be considered in deciding whether to offer the organ transplant? $?^{204}$ Should we favor the thirty-eight-year-old patient with three young children over the seventy-year-old patient with no dependents?

199. See Charles T. Carlstrom \& Christy D. Rollow, The Rationing of Transplantable Organs: A Troubled Lineup, 17 CATO J. 163, 168 (1997).

200. See Robert F. Weir, The Issue of Fairness in the Allocation of Organs, 20 J. CoRP. L. 91, 97 (1995).

201. Health care providers often place greater importance on medical utility than on fairness in discussing organ allocation. See id. at 102. Indeed, UNOS has stated that "[p]atient survival is the ultimate goal of organ allocation policy. In order to achieve the greatest net benefit for the entire transplant population, the policy must be designed to attain the longest patient survival time overall ...." UNOS Principles and Objectives of Equitable Organ Allocation, supra note 32 .

202. See supra notes 56-57 and text accompanying notes.

203. See Ingrid Kinkopf-Zajac, Assessing Patient Compliance in the Selection of Organ Transplant Recipients, 6 HEALTH MATRIX 503, 505 (1996). The patient's compliance with the prescribed treatment will obviously affect the success of the transplant. The patient must take medications to prevent the body's immune system from rejecting the organ. This drug therapy must be taken for the duration of the patient's life and often causes undesirable side effects ranging from increased body hair to anemia, diabetes, and seizures. See id. at 506 \& n.7.

204. See Nicholas Rescher, The Allocation of Exotic Medical Lifesaving Therapy, 79 ETHICS 173, 178-79 (1969) (arguing that society would be warranted in taking a patient's family role, as well as his potential future and his past service to society, into account when selecting individuals for exotic medical treatment). 
Should we favor Mickey Mantle over the average Joe? Should a patient with a fifteen-year drinking problem be given a new liver? What about using the patient's ability to pay as a factor? Perhaps organs should be allocated to the patients who can afford the considerable costs of transplant surgery and drug medications. The plethora of potential factors in allocating organs ensures continued debate.

\section{B. Who Should Determine Organ Allocation Policy?}

These considerations, however, prompt the more difficult question-who should decide which of these factors are used to formulate an acceptable organ allocation policy? Consider the possible candidates:

1. Health Care Professionals. When Congress passed NOTA in 1984 , it intended to leave organ transplant policy to the health care providers. ${ }^{205}$ This determination accorded with the deeply rooted belief that transplant professionals were the most knowledgeable and therefore best suited to make these policy decisions. After the Final Rule was issued, many people continued to argue that organ allocation policy should be left to transplant professionals. ${ }^{206}$ In fact, HHS included some language in the Final Rule that seemed to reaffirm this belief:

The Department believes that the transplantation network must be operated by professionals in the transplant community, and that both allocation and other policies of the OPTN should be developed by transplant professionals, in an open environment that includes the public, particularly transplant patients and donor families. It is not the desire or intention of the Department to interfere in the practice of medicine. ${ }^{207}$

Still, the notion that professionals should control the delivery of health care has weakened in recent years. Many attribute the high costs of health care to the fact that health care providers exercise considerable discretion in deciding what services are purchased. ${ }^{208}$

\footnotetext{
205. See supra notes 130-37 and accompanying text.

206. See Hearing on the Final Rule, supra note 7, at 139 (statement of Lawrence G. Hunsicker, President, UNOS).

207. Organ Procurement and Transplantation Network, 63 Fed. Reg. at 16,296, 16,300 (1998)

208. See, e.g., Barry R. Furrow, Incentivizing Medical Practice: What (If Anything) Happens
} 
Rising concerns over costs have spurred market-oriented strategies in financing and delivering health care, and these strategies have taken away some of the control that providers enjoyed. ${ }^{209}$ Increased competition in health care places a greater emphasis on consumer and patient choice. ${ }^{210}$

HHS has also recognized that the old paradigm of professional dominance is no longer wise. The recent clarification of the Final Rule includes a provision limiting the influence of transplant physicians on the OPTN board of directors. ${ }^{211}$ The board must consist of approximately fifty percent transplant physicians and at least twentyfive perfect transplant candidates, transplant recipients, and organ donors. ${ }^{212}$ Additionally, the board must include representatives of OPOs, transplant hospitals and coordinators, and the general public. ${ }^{213}$ These developments indicate that the paradigm of professional dominance is waning.

2. Consumers. Following the increased emphasis on health care consumerism, several scholars have argued for a market-based approach to organ transplant policy. In general, these scholars have focused greater attention on the use of financial incentives in procuring organs than in allocating them. ${ }^{214}$ James Blumstein and Henry Hansmann, however, have separately advocated that the

to Professionalism, 1 WID. L. SYMP. J. 1, 12-13 (1996) (discussing how physician control of health care expenditures has resulted in health care cost inflation); Maxwell J. Mehlman, The Patient-Physician Relationship in an Era of Scarce Resources: Is There a Duty to Treat?, 25 CONN. L. REV. 349, 350 (1993) (noting that physicians "play the dominant role in determining the care that patients receive").

209. See Mehlman, supra note 208, at 351; see also Mark A. Hall, Institutional Control of Physician Behavior: Legal Barriers to Health Care Cost Containment, 137 U. PA. L. REV. 431, 441-44 (1988) (observing that many cost-control reforms seek to influence physician behavior).

210. See, e.g., Rand E. Rosenblatt, Health Care, Markets, and Democratic Values, 34 VAND. L. REV. 1067, 1079-81 (1981) (discussing arguments for harnessing individual consumer choice to curtail rising health care costs).

211. See Organ Procurement and Transplantation Network, 64 Fed. Reg. at 56,658 (to be codified at 42 C.F.R. $§ 121.3(a)$ ).

212. See id.

213. See id. (to be codified at 42 C.F.R. $§ 121.3$ (a)(iii)).

214. See Lloyd R. Cohen, Increasing the Supply of Transplant Organs: The Virtues of a Futures Market, 58 GeO. WASH. L. REV. 1, $32-43$ (1989); Thomas G. Peters, Life or Death: The Issue of Payment in Cadaveric Organ Donation, 265 JAMA 1302, 1304-05 (1991); Richard Schwindt \& Aidan R. Vining, Proposal for a Future Delivery Market for Transplant Organs, 11 J. Health Pol., Pol'y \& L. 483, 489-97 (1986). Indeed, Pennsylvania recently announced a controversial initiative to increase organ donations by providing a $\$ 300$ stipend to help pay for the funeral costs of organ donors. See Kathleen Kerr, Pa. May OK Pay for Organ Donations, NEWSDAY, June 8, 1999, at A6. 
market should be used to distribute organs. ${ }^{215}$ Contrary to the widespread belief that a market approach for allocation would favor the rich, Hansmann has suggested that market-based allocation might actually lead to a more egalitarian distribution compared to the current system. ${ }^{216}$ Blumstein has argued that the use of financial incentives would foster pluralism and diversity in medical care. ${ }^{217}$ This Note does not attempt to explore the merits of these arguments. It is sufficient to say at this juncture that most policymakers and commentators remain reluctant to sanction the sale or purchase of human body parts. ${ }^{218}$ As noted earlier, both federal and state laws prohibit the sale or purchase of vascular organs. ${ }^{219}$

3. Federal Agencies. Arguably, federal agencies should determine the factors used to formulate the policy on how organs are distributed. Not surprisingly, this seems to be the position taken by HHS. The Final Rule cites certain failures of the current providerdominated system as justification for federal intervention:

Another flaw in current OPTN policies pertains to disclosure of information. The statute requires the Secretary to provide information to patients, their families, and physicians about transplantation. Current policies in this area do not give patients, their families, and physicians the timely information they need to help in selecting a transplant hospital. ${ }^{220}$

215. See generally James F. Blumstein, The Use of Financial Incentives in Medical Care: The Case of Commerce in Transplantable Organs, 3 HEALTH MATRIX 1 (1993) [hereinafter Blumstein, The Use of Financial Incentives in Medical Care]; Henry Hansmann, The Economics and Ethics of Markets for Human Organs, 14 J. HeALTH POL., POL'Y \& L. 57 (1989).

216. See Hansmann, supra note 215, at 80-81 (arguing that greater market influence in organ allocation decisions would supplant the "monolithic, national system of control that we currently have in [UNOS]").

217. See Blumstein, The Use of Financial Incentives in Medical Care, supra note 215, at 13 (suggesting that allocating organs by price would curtail the current administrative allocation bias favoring prosperous white males because insurance plans, which pay for most organ transplants, would bear the costs).

218. The World Health Organization holds that the sale of organs violates the Universal Declaration of Human Rights. See Rick Weiss, A LOOK AT ... The Body Shop; At the Heart of an Uneasy Commerce, WASH. POST, June 27, 1999, at B3. George Annas, a noted lawyer and medical ethicist at Boston University, has stated that "commodifying organs through direct purchase and sale is a bad idea." Kerr, supra note 214, at A6. Dr. Francis Delmonico of Massachusetts General Hospital believes that "[s]ociety is not prepared to allow for your body to be bought and sold." Editorial, A Price Tag on Life, InDIANAPOLIS STAR, May 15, 1999, at A14.

219. See supra notes 28-29, 69 and accompanying text.

220. Organ Procurement and Transplantation Network, 63 Fed. Reg. 16,296, 16,298 (1998). 
The federal government can perhaps correct these deficiencies. The Final Rule continues: "[T]he Department has an important and constructive role to play, particularly on behalf of patients. Human organs that are given to save lives are a public resource and a public trust." 221 Therefore, the Secretary of HHS "may direct the OPTN to adopt a policy, or may develop a policy that the OPTN must follow." 222 Perhaps some amount of government regulation is necessary because the beneficiaries (transplant donors and recipients) are unable to protect their own interests.

Many are critical of federal regulation of organ transplantation. ${ }^{223}$ The public still considers government bureaucracy too inefficient and too slow to adapt to changing ideas. James Blumstein has argued against a monolithic bureaucratic system because it runs counter to the prevailing pluralism and diversity in health care policy today. ${ }^{224}$ In doing so, Blumstein concedes that government regulation might be justified if organ transplantation were viewed as somehow "different" from the rest of health care. ${ }^{225}$ Believing transplantation to be a part of ordinary medical care, Blumstein concludes that there is no basis for special treatment of organ transplantation. ${ }^{226}$

Nonetheless, a good argument remains for treating organ transplantation differently than ordinary medical care. Under the Medicare and Medicaid programs, the federal government pays for more than half of the transplant surgeries in the United States. ${ }^{227}$ The federal government pays for nearly all kidney transplant surgeries under

221. Id. at 16,300 .

222. Id.

223. See, e.g., Patient Access to Transplantation Coalition Statement, supra note 58 ("Do federal policymakers really know better than transplant physicians and surgeons what is best for their patients? We think not...."); National Organ Transplant Policy Draws Fire in Louisiana; Doctors Fear State Will Come Up Short, Baton Rouge Sunday Advoc., Mar. 29, 1998, at 9B ("'It seems to me the executive branch of government is trying to mandate health care and trying to say that it knows more than the people who care about the patient."') (quoting Dr. Douglas P. Slakey).

224. See James F. Blumstein, Government's Role in Organ Transplantation Policy, 14 J. HeAlth POL., POL'Y \& L. 5, 21 (1989) [hereinafter Blumstein, Government's Role]; Blumstein, The Use of Financial Incentives in Medical Care, supra note 215, at 11-13.

225. See Blumstein, Government's Role, supra note 224, at 36.

226. See id.

227. See Organ Donations: Hearings Before the Subcomm. on the Departments of Labor, Health and Human Services, and Education, and Related Agencies of the Senate Comm. on Appropriations, 105th Cong. 10 (1998) (statement of Donna Shalala, Secretary of Health and Human Services) (visited Aug. 17, 1999) <http://www.hhs.gov/progorg/asl/testify/t980910a.txt> (on file with the Duke Law Journal). 
the End-Stage Renal Disease program. ${ }^{228}$ Perhaps organ transplantation is unique in medical care, since a standard unit-transplant organs - can be identified and measured. ${ }^{229}$ In no other area of medicine can the allocation of a single resource determine the well-being of a patient.

4. The States. The new state laws on organ allocation raise the notion that state governments should determine how organs are allocated. Allocation by the states, however, does not seem logical if one believes that biological matching and broader equity should be considerations in organ allocation. There has never been any contention that the states would balance these factors with their desire to keep organs procured within the state. Moreover, while the states inherently possess the power to protect their citizens' health and welfare, it is doubtful that state officials generally have expertise in the field of organ transplantation. Thus, the state laws that restrict out-of-state organ transfers seem to be an inappropriate way for the states to argue their case for the local preference in allocation. More appropriate actions would be for state legislatures to pass resolutions and submit them to Congress, for citizens to lobby their members of Congress for action, or for the state Attorneys General to challenge the Final Rule in courts.

5. The Courts. The enactment of state laws that restrict out-ofstate organ transfers may require the courts to enter the policy debate concerning organ allocation. Judges, who will inevitably face policy questions in deciding these cases, should keep in mind the broader policy implications of their decisions. For instance, courts using the dormant Commerce Clause to strike down the state organ allocation laws should consider the curious state of affairs that would result if these laws were upheld. Absent court intervention, organ allocation in the United States could devolve into a fragmented system, with some transplant centers following UNOS guidelines and others following their states' laws. This result would probably be un-

228. See Blumstein, Government's Role, supra note 224, at 11; see also 42 U.S.C. $\$ 426-1$ (1994)

229. It has been argued that there must be pluralism and diversity in medical care because it is impossible to identify standard "products" of medical care that can be precisely measured in standard units. See Alain C. Enthoven, Health Plan: The Only Practical Solution TO THE SOARING COST OF MEDICAL CARE 1-9 (1980). 
satisfactory for most people, even those who advocate pluralism and diversity in organ transplantation.

Though the courts should invalidate the state laws restricting broader organ sharing, the courts are perhaps the poorest institutions to make the broader organ allocation decisions that need to be made. Federal judges possess neither expertise in organ transplant policy nor an electoral mandate from voters. Thus, judges should limit their judicial rulemaking to the specific legal conflicts presented to them.

\section{CONCLUSION}

In promulgating the Final Rule of April 2, 1998, HHS tried to bring finality to the way in which organs are allocated in the United States. Instead, the Final Rule has prompted more questions. As this Note has shown, the attempts by some states to restrict out-of-state organ transfers should fail because the dormant Commerce Clause requires that the courts strike down these state laws. These attempts ultimately raise broader organ allocation issues, the resolution of which should be left to Congress. Only Congress can determine whether HHS ultimately should control allocation policy, whether the transplant community should be left to make these decisions, or whether market forces should govern organ procurement and distribution. Though there is some indication that Congress will confront these issues in the near future, ${ }^{230}$ it is likely that organ allocation will remain a major point of contention for some time.

230. On October 13, 1999, the House Commerce Committee approved a bill that would give UNOS the authority to make all substantive decisions regarding organ allocation and severely limit the federal government's oversight of organ transplant policy. See H.R. 2418, 106th Cong. $\$ 3$ (1999); Associated Press, Bill Strips Feds of Authority Over Transplants, SALt LAKE TRIB., Oct. 14, 1999, at A10. Additionally, the bill would allow the states to pass laws keeping organs within the states. See Associated Press, supra. The Senate is considering similar legislation. See Stolberg, supra note 11, at A1. However, President Clinton would probably veto such a bill if it passed Congress. See Associated Press, supra. 